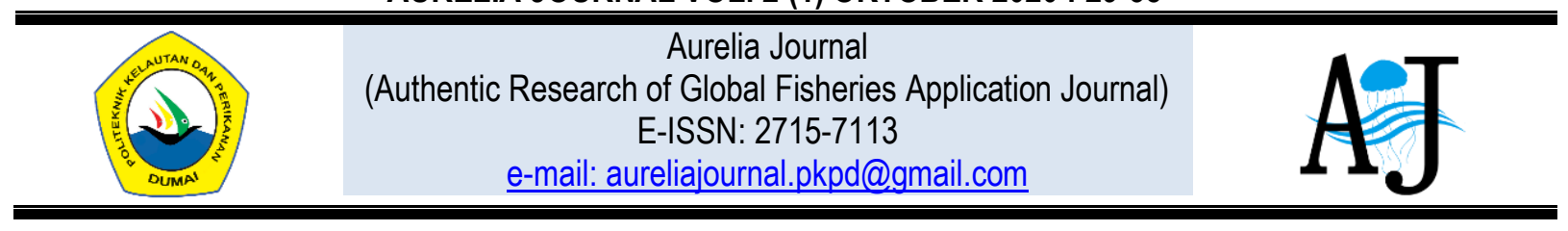

\title{
KAJIAN PENGENDALIAN MUTU PRODUK TUNA LOIN PRECOOKED FROZEN MENGGUNAKAN METODE SKALA LIKERT DI PERUSAHAAN PEMBEKUAN TUNA X
}

\section{STUDY OF QUALITY CONTROL OF TUNA LOIN PRECOOKED FROZEN PRODUCTS USING THE LIKERT SCALE METHOD IN TUNA FREEZING COMPANY $X$}

\author{
Sumartini ${ }^{1 *}$, Kurnia Sada Harahap ${ }^{1}$, Sthevany ${ }^{1}$ \\ 1Politeknik Kelautan dan Perikanan Dumai, JI. Wan Amir, No.1, Kelurahan Pangkalan Sesai, \\ Kecamatan Dumai Barat, Kota Dumai, Provinsi Riau, Indonesia \\ *Korespondensi: tinny.sumardi@gmail.com (Sumartini) \\ Diterima 9 September 2020 - Disetujui 9 Oktober 2020
}

\begin{abstract}
ABSTRAK. Industri pengolahan pangan dan hasil perikanan secara simultan meningkatkan concern di bidang keamanan pangan dan pengendalian mutu. Pengendalian mutu yang paling dasar adalah GMP (Good Manufacturing Practices) dan SSOP (Sanitation Standard Operating Procedure) sesuai dengan standar yang telah ditetapkan. Tujuan dari penelitian ini adalah untuk mengetahui dan mengkaji sistem pengendalian mutu pada proses pengolahan Tuna Loin Precooked Frozen sebagai dasar kunci pengambilan strategi dan kebijakan dalam penerapan pengendalian pangan dan hasil perikanan dalam skala eksport. Metode yang digunakan pada kajian pengendalian mutu ini menggunakan metode Skala Likert yang merupakan metode kuantitatif pengukuran pendapat seseorang menggunakan kuesioner untuk mengetahui skala sikap terhadap objek tertentu. Proses pengolahan Tuna Loin Precooked Frozen di Perusahaan Pembekuan Tuna $\mathrm{X}$ terdapat beberapa proses yaitu: Penerimaan bahan baku, Pelelehan, Penyiangan, Penyortiran, pemasakan, Pendinginan (spray I dan II), Pengkulitan, Pembersihan, Pengemasan (I), Pemvakuman, Pendeteksi Logam, Pembekuan, Pengemasan (II), Penyimpanan beku dan Pemuatan. Penilaian skala likert dari responden terhadap pengendalian mutu dengan hasil skor yang diperoleh dari kuesioner penerapan GMP (Good Manufacturing Practices) 92\%, penerapan SSOP (Sanitation Standard Operating Procedure) $94,4 \%$ serta Pengendalian Mutu Terpadu 92\%. Berdasarkan hasil tersebut maka Perusahaan Pembekuan Tuna $X$ dapat menjadi alternatif industri pangan dan pengolahan hasil perikanan yang menerapkan dan melakukan pengendalian manajemen mutu secara konsisten.
\end{abstract}

KATA KUNCI: GMP, SSOP, Skala Likert

ABSTRACT. The food and fishery product processing industries are simultaneously raising concerns in the fields of food safety and quality control. The most basic quality control is GMP (Good Manufacturing Practices) and SSOP (Sanitation Standard Operating Procedure) in accordance with predetermined standards. The purpose of this study was to determine and examine the quality control system in the processing of Tuna Loin Precooked Frozen as a key basis for making strategies and policies in the application of control of food and fishery products on an export scale. The method used in this quality control study uses the Likert scale method which is a quantitative method of measuring a person's opinion using a questionnaire to determine the scale of attitudes towards certain objects. The processing of Tuna Loin Precooked Frozen at Tuna X Freezing Company has several processes, namely: Receiving raw materials, Melting, Weeding, Sorting, cooking, cooling (spray I and II), Barking, Cleaning, Packaging (I), Vacuuming, Metal Detecting, Freezing, Packaging (II), Freezing storage and Loading. Likert scale assessment of respondents on quality control with the results obtained from the questionnaire on the application of GMP (Good Manufacturing Practices) 92\%, the application of SSOP (Sanitation Standard Operating Procedure) 94.4\% and Integrated Quality Control 92\%. Based on these results, the Tuna X Freezing Company can be an alternative for the food and fishery product processing industries that implement and carry out quality management controls consistently.

KEYWORDS: GMP, SSOP, Likert Scale 


\section{Pendahuluan}

Perkembangan perusahaan perikanan yang semakin meningkat terutama pada kegiatan ekspor membuat suatu perusahaan perikanan harus mencapai target yaitu membuat produk yang dapat bersaing dengan negara lainnya baik pada kualitas atau mutu agar dapat memenuhi kebutuhan konsumen dan dapat memberikan rasa kepuasan pelanggan dengan menghasilkan produk yang baik sesuai standar yang telah ditetapkan. Dengan demikian, perlunya dilakukan pengendalian mutu untuk menghasilkan produk yang sesuai standar. Hasil perikanan merupakan bahan pangan yang mudah rusak (perishable food) oleh mikroorganisme pembusuk dan enzim, sehingga perlu penanganan yang baik untuk mempertahankan mutunya, dengan terjaminnya mutu dan kualitas dapat mendorong perusahaan hasil perikanan untuk memenuhi standar kesehatan atau mengurangi perusahaan untuk bersaing dan meningkatkan pendapatan (income) ataupun devisa negara (Saragih, 2013).

Ikan merupakan salah satu bahan pangan yang memiliki kandungan gizi tinggi yang diperlukan dalam tubuh. Salah satu ikan yang paling sering dijadikan sebagai bahan baku pangan adalah ikan tuna. Ikan tuna (Thunnus sp) merupakan hasil perikanan yang mempunyai nilai ekonomis penting baik sebagai komoditi ekspor maupun sebagai konsumsi lokal. Ikan tuna (Thunnus sp) adalah jenis ikan dengan kandungan protein yang tinggi dan lemak yang rendah. Ikan tuna (Thunnus sp) mengandung protein antara 22,6 - 26,2 g/100 g daging, lemak antara 0,2 - 2,7 g/100 g daging (Hadinoto \& Idrus, 2018). Tuna loin masak beku merupakan produk olahan tuna yang mengalami pemasakan, pembentukan loin dan pembekuan. Prinsip pada pengolahan ikan ini adalah untuk mempertahankan masa simpan produk dan juga peningkatan nilai tambah pada produk. Pada proses pengolahan perlunya dilakukan pengendalian mutu berupa pengawasan pada setiap kegiatan produksi yaitu penerapan HACCP, GMP, dan SSOP untuk menjamin terhadap jaminan mutu keamanan produk perikanan.

Perusahaan Pembekuan Tuna PT. X merupakan perusahaan yang bergerak di bidang perikanan yaitu Tuna Loin masak beku. Perusahaan tersebut telah melaksanakan kegiatan ekspor-import, oleh sebab itu Perusahaan Pembekuan Tuna PT. X perlu memiliki jaminan atas mutu dan kualitas produk yang mereka miliki, seperti halnya sertifikat SKP (Sertifikat Kelayakan Pengolahan), HACCP (Hazard Analysis Critical Control Point), GMP (Good Manufacturing Practices), SAFE (Dolphin-Safe Tuna), Orthodox Union (U), Nomor EU, dan Sertifikat Jaminan Halal (SJH). Kegiatan ekspor produk perikanan juga harus selalu memperhatikan mutu terhadap produk. Berdasarkan latar belakang diatas penulis mengambil judul "Kajian Pengendalian Mutu Produk Tuna Loin Precooked Frozen Menggunakan Metode Skala likert di Perusahaan Pembekuan Tuna PT. X" agar penulis mengetahui sejauh mana penerapan sistem jaminan dan pengendalian mutu pada Pengolahan Tuna Loin Precooked Frozen di Perusahaan Pembekuan Tuna PT. X.

\section{Bahan dan Metode}

Kegiatan ini dilaksanakan di Perusahaan Pembekuan Tuna PT. X pada tanggal 2 Maret 2010. Teknik analisis data yang digunakan menggunakan metode Skala Likert. (Sugiyono, 2012) Merupakan metode pengukuran yang digunakan untuk mengukur pendapat seseorang menggunakan kuesioner untuk mengetahui skala sikap terhadap suatu objek tertentu. Pada skala likert ini kuesioner yang diberikan memberikan skor pada setiap jawaban yaitu 1-5. skor 1 (satu) untuk pendapat/jawaban sangat tidak setuju sedangkan skor 5 (lima) untuk pendapat/jawaban sangat setuju.

Menurut Retnawati (2010), Model angket yang paling sering digunakan di Indonesia berbentuk rating scale atau lebih dikenal dengan model Likert. Instrumen model Likert ini relatif mudah membuatnya, dan responden juga mudah meresponnya. Namun kelemahan dari instrumen ini adalah adanya kecenderungan responden untuk mengisi instrumen sesuai dengan harapan masyarakat (desireability bias). Instrumen dengan skala ini merupakan bentuk yang sering digunakan peneliti untuk melakukan pengukuran. Misalnya Wahyono, Hardianto, \& Miyarso (2014) mengukur indeks etor kerja 
belajar siswa menggunakan skala 1-5, dan Retnawati (2014) mengukur minat belajar menggunakan skala Likert.

Setelah mendapat jawaban responden, totalkan skor yang diperoleh menggunakan rumus:

Total skor $=\mathrm{T} \times \mathrm{Pn}$

Keterangan: $\mathrm{T}$ = Total Jumlah Responden; $\mathrm{Pn}=$ Pilihan angka skor likert

Indeks $\%=$ Total skor $/ \mathrm{Y} \times 100$

(Y) dihitung menggunakan rumus:

$\mathrm{Y}=$ Skor tertinggi likert $\times$ jumlah responden

Sebelum menyelesaikan hasil likert kita harus mengetahui interval (rentang jarak) dan interpresentasi persen agar mengetahui penilaian dengan metode mencari interval skor persen (I). Rumus Interval:

Dengan I $=100 / 5$

$=20$

ini adalah intervalnya jarak dari terendah 0\% hingga tertinggi $100 \%$ ).

Berikut skornya berdasarkan interval:

$-0 \%-19,99 \%=$ Sangat Tidak Setuju

$-20 \%-39,99 \%=$ Kurang Setuju

$-40 \%-59,99 \%=$ Ragu

$-60 \%-79,99 \%=$ Setuju

$-80 \%-100 \%=$ Sangat Setuju.

Skala Likert menurut Djaali (2008) ialah skala yang dapat dipergunakan untuk mengukur sikap, pendapat, dan persepsi seseorang atau sekelompok orang tentang suatu gejala atau fenomena pendidikan. Skala Likert adalah suatu skala psikometrik yang umum digunakan dalam kuesioner, dan merupakan skala yang paling banyak digunakan dalam riset berupa survei dan penelitian karena merupakan skala yang paling mudah digunakan.

\section{Hasil dan Pembahasan}

\subsection{Proses Pengolahan Tuna Loin Precooked Frozen}

Proses pengolahan tuna loin masak beku di Perusahaan Pembekuan Tuna PT. X ada beberapa tahapan proses yaitu: Penerimaan bahan baku, Pelelehan (Thawing), Penyiangan (Butchering), Penyortiran, Pemasakan (Cooking), Pendinginan (Spray I dan II), Pengkulitan (Skinning), Pembersihan (Cleaning), Pengemasan (Packing I), Pemvakuman, Pendeteksi logam (Metal detector), Pembekuan, Pengemasan (Packing II), Penyimpanan beku dan pemuatan.

\section{A. Penerimaan Bahan Baku}

Bahan baku Perusahaan Pembekuan Tuna PT. X adalah bahan baku yang berasal dari kapal suplier di pelabuhan yang berlokasi dibagian belakang Perusahaan Pembekuan Tuna PT. $X$ yang terdiri dari 62 suplier dan jumlah kapal 148 serta kapal milik Perusahaan Pembekuan Tuna PT. X. Jenis bahan baku yang digunakan oleh perusahaan adalah tuna jenis Yellowfin, Big eye, Baby tuna dan Cakalang.

Ikan yang diterima dari kapal dalam keadaan beku, pembongkaran dilakukan dengan cara ikan dimasukkan ke dalam palet dilakukan pengecekan suhu dengan suhu penerimaan bahan baku standar Perusahaan Pembekuan Tuna PT. X adalah $-18^{\circ} \mathrm{C}$ dan pencatatan tanggal masuk oleh QC kemudian 
ikan disimpan kedalam cold storage. Menurut Dirjen Penguatan Daya Saing (2017) Cold storage adalah suatu ruangan yang dilengkapi dengan anteroom dan berfungsi untuk menyimpan/mengawetkan ikan beku pada suhu ruangan $-25^{\circ} \mathrm{C}$ atau lebih rendah.

Bahan baku yang diterima oleh Perusahaan Pembekuan Tuna PT. X adalah ikan cakalang dan tuna sirip kuning sebelum digunkan dilakukan pengujian secara organoleptik, mikrobiologi dan kimia (Histamin) dengan cara dilakukan pengambilan sampling. Standar kadar Histamin bahan baku yang disyaratkan oleh pihak perusahaan adalah 50 ppm. The Food and Drug Administration (FDA 2011) menetapkan batas standar keamanan histamin adalah $5 \mathrm{mg} / 100 \mathrm{~g}(50 \mathrm{ppm})$, sedangkan Uni Eropa menetapkan bahwa kandungan rata-rata histamin dalam ikan tidak boleh lebih dari $10 \mathrm{mg} / 100 \mathrm{~g}$ (100 ppm). Histamin merupakan parameter penting dalam perdagangan ekspor tuna agar dapat diterima baik di United States (US), Uni Eropa (UE), maupun jepang yang kadarnya sangat dibatasi (Wodi, Trilaksani dan Nurilmala, 2018).

\section{B. Pelelehan (Thawing)}

Thawing adalah proses pelelehan pada ikan beku yang bertujuan untuk memudahkan proses selanjutnya. Menurut Sari (2019) sebelum produk beku digunakan atau diolah lebih lanjut perlu dilakukan pencairan (thawing) dengan menggunakan metode yang tepat. Proses Pelelehan (Thawing) pada Perusahaan Pembekuan Tuna PT. X dilakukan dengan cara ikan dikeluarkan dari cold storage menggunakan Forklift menuju area thawing, lalu ikan dimasukkan kedalam bak yang berisi air. Pengecekan suhu ikan dilakukan setiap 15 menit sekali dengan mengambil 12 sampel dengan menggunakan sistem random sampling. Berdasarkan Arieska dan Herdiani (2018) Simple Random Sampling atau biasa disingkat Random Sampling merupakan suatu cara pengambilan sampel dimana tiap anggota populasi diberikan opportunity (kesempatan) yang sama untuk terpilih menjadi sampel.

Ikan sebelum di thawing bersuhu $-18^{\circ} \mathrm{C}$. Proses thawing dilakukan selama \pm 1 jam dengan suhu mencapai $\left(-6^{\circ} \mathrm{C}\right)-\left(-4^{\circ} \mathrm{C}\right)$. setelah itu, ikan diangkat menggunakan katrol dan dibawa ke proses selanjutnya.

\section{Penyiangan (Butchering)}

Butchering merupakan proses yang dilakukan untuk menghilangkan isi perut ikan. Vatria (2010) menyatakan bahwa tahapan penyiangan yaitu dilakukan pembuangan isi perut, sisik dan insang, karena merupakan sumber kontaminasi bakteri yang dapat mempercepat proses pembusukkan pada bahan baku.

Proses Butchering dilakukan secara manual oleh karyawan yang menggunakan pisau stainless dengan cara membelah pada bagian perut ikan, kemudian membuang isi perut ikan. Butchering dilakukan menggunakan mesin convayer yang dialiri dengan air diatasnya untuk menyiram dan dapat mencuci ikan. Ikan yang di Butchering adalah ikan yang telah selesai di thawing dengan suhu yang telah sesuai dengan standar PT. XY yaitu $\left(-6^{\circ} \mathrm{C}\right)-\left(-4^{\circ} \mathrm{C}\right)$ sedangkan suhu setelah di Butchering adalah $-2^{\circ} \mathrm{C}$.

\section{Penyortiran}

Penyortiran merupakan pemisahan ikan berdasarkan ukuran yang dilakukan secara manual oleh karyawan. Tujuan dari penyortiran adalah untuk mendapatkan ukuran seragam ikan, agar pada saat pemasakan ikan dapat matang secara merata.

\section{E. Pemasakan (Cooking)}

Setelah proses penyortiran dan penyusunan ikan telah selesai selanjutnya adalah dilakukan pemasakan. Ikan sebelum dimasak bersuhu $0^{\circ} \mathrm{C}$, ikan dimasak pada malam hari agar dapat langsung di proses pada pagi hari. Perusahaan Pembekuan Tuna PT. X memiliki 4 (empat) buah mesin cooker dimana satu mesin cooker dapat memuat enam troly. Suhu pemasakan ikan adalah $90^{\circ} \mathrm{C}$ dengan lama pemasakan berbeda berdasarkan ukuran ikan. 
Standar ikan masak di Perusahaan Pembekuan Tuna PT. X adalah apabila suhu pusat ikan telah mencapai $65-70^{\circ} \mathrm{C}$, jika suhu pusat ikan belum memenuhi maka dilakukan pemasakan lagi hingga suhu pusat ikan mencapai standar. Proses pemasakan yang digunakan adalah pengukusan dengan menggunakan uap panas. Menurut Sipayung, Suparmi dan Dahlia (2014) pengukusan (steaming) merupakan salah satu metode pemasakan yang menggunakan panas. Pemasakan dengan metode ini dapat mempertahankan cita rasa alami dari bahan makanan dengan terjadinya perpindahan panas secara konveksi dari uap panas ke bahan makanan yang sedang dikukus.

Menurut Rahman, Sukmiwati dan Dahlia (2015), Penggunaan panas dan waktu dalam proses pemanasan bahan pangan sangat berpengaruh pada bahan pangan. Pengaruh pemanasan terhadap komponen daging ikan dapat menyebabkan perubahan fisik dan kimia. Hal ini sesuai dengan pendapat Dhanapal, Reddy, Venkateswarlu, Reddy dan Basu (2012), menyatakan bahwa penyusutan kadar lemak pada ikan yang telah mengalami proses pemasakan yang disebabkan karena hilangnya cairan jaringan selama proses pemasakan tersebut.

\section{F. Pendinginan (Spray I dan II)}

Setelah proses cooking selesai selanjutnya ikan didinginkan dengan menggunakan water spray, yang tujuannya selain mendinginkan ikan juga dapat mengembalikan kadar air ikan yang hilang pada proses pemasakan. Pendinginan juga berfungsi sebagai agar kulit dengan daging tidak lengket yang akan mempersulit proses selanjutnya yaitu proses pembuangan kulit (skinning). selain itu pendinginan adalah salah satu cara yang umum digunakan untuk memperlambat kerusakan pada produk-produk hasil perikanan (Mohammed dan Hamid, 2011),

Proses pendinginan memiliki dua tahap yaitu spray I selama 15 menit dan spray II sebagai spray lanjutan selama 35-50 menit. Setelah itu QC melakukan pengecekan suhu ikan, ikan yang sudah mencapai suhu $40^{\circ} \mathrm{C}$ akan dapat dilanjutkan ke proses selanjutnya. Size ikan akan mempengaruhi waktu pendinginan. Ikan yang berukuran besar maka proses pendinginannya membutuhkan waktu yang lama.

\section{G. Pengkulitan (Skinning)}

Skinning adalah proses pembuangan kepala dan pengikisan kulit ikan yang menggunakan pisau untuk mendapatkan daging tanpa kulit. Pada proses skinning hal yang harus diperhatikan adalah bagian perut dan badan ikan. Daging bagian perut ikan tidak boleh patah atau tanggal sedangkan pada bagian badan ikan tidak boleh botak (daging ikut terkikis bersama kulit), dalam memperhatikan ini teknik dalam memegang pisau sangat diperhatikan.

\section{H. Pembersihan (Cleaning)}

Cleaning adalah merupakan pembersihan ikan dari daging coklat, kulit, tulang dan sisik. Proses Cleaning dilakukan dengan cara ikan dibelah menjadi 4 (empat) bagian kemudian ikan dibersihkan satu persatu dari daging hitam dengan cara dikikis untuk mendapatkan loin yang bersih. Menurut Mariah (2011) Pembuangan daging gelap ini bertujuan untuk memperkecil tingkat kadar histamin. Hal ini dinyatakan menurut Hafiludin (2011), kandungan daging merah yang cukup tinggi yang biasanya mengandung cukup banyak senyawa histidin bebas didalamnya, sehingga merupakan media yang baik untuk pertumbuhan bakteri pembentuk histidin

Dari hasil pengikisan daging hitam akan menghasilkan shreded yaitu daging putih yang terikut dari pengikisan. Daging hitam, tulang, dan sisik dipisahkan yang kemudian akan diambil oleh karyawan bagian limbah yang akan diolah menjadi fish meal.

\section{Pengemasan (Packing) dan Pemvakuman}

Pengemasan bertujuan untuk melindungi produk terhadap kontaminasi dari luar. Proses pengemasan di Perusahaan Pembekuan Tuna PT. X dilakukan dengan loin dimasukkan kedalam 
plastik dan kemudian ditimbang dengan berat $5,5 \mathrm{~kg}$ perkemasan. Jenis kemasan yang digunakan adalah plastik jenis LLDPE (Linear Low Density Polyetilen).

Menurut Nofreeana, Masi dan Deviarni (2017), Faktor pengemasan dapat mempengaruhi pertumbuhan mikro-organisme seperti kapang/jamur dan bakteri. Pengemasan dengan menggunakan vakum dapat menghambat pertumbuhan bakteri aerob. Suhu dan lamanya pengasapan juga akan mempengaruhi aktifitas air (Aw) yang ada pada daging Ikan. Hal ini sesuai dengan Kusnandar (2010), Aktivitas air (Aw) merupakan parameter yang berpengaruh pada stabilitas dan keawetan pangan, laju reaksi kimia, aktivitas enzim dan pertumbuhan mikrobia. Setelah loin dikemas kemudian dilakukan pemvakuman menggunakan mesin vakum. Pengemasan vakum adalah sistem pengemasan hampa udara dimana tekanannya kurang dari 1 atm dengan cara mengeluarkan $\mathrm{O}_{2}$ dari proses masa simpan, sehingga memperpanjang umur simpan (Nasution, Ilsa dan Sari, 2016). sebagaimana dinyatakan Astawan, Nurwitri, Suliantari, dan Rochim (2015), Salah satu teknik untuk memperpanjang masa simpan dan menjaga kualitas sensori suatu produk pangan adalah dengan pengemasan vakum. Prinsip pengemasan vakum adalah mengeluarkan semua udara dari dalam kemasan, kemudian ditutup rapat sehingga tercipta kondisi tanpa oksigen dalam kemasan tersebut.

\section{J. Pendeteksian Logam}

Pendeteksi logam dilakukan untuk memastikan loin tidak mengandung logam yang dapat membahayakan kesehatan konsumen. Pendeteksi logam dilakukan dengan cara loin yang telah dikemas dijalankan pada mesin metal detector. Metal detector akan berbunyi dan berhenti apabila loin mengandung logam.

Menurut Atmiasri dan Rochman (2011), Sensor logam atau dikenal dengan metal detector ialah termasuk sensor induktif. Sensor ini biasanya digunakan dalam industri dan sistem keamanan. Hal ini dimaksudkan agar produk tersebut aman dikonsumsi oleh konsumen.

\section{K. Pembekuan}

Pembekuan dilakukan dengan cara ikan yang telah di vakum kemudian di susun kedalam rak dan dimasukkan kedalam ABF (Air Blast Freezer) bersuhu $(-35)^{\circ} \mathrm{C}-(-40)^{\circ} \mathrm{C}$ dengan lama pembekuan 8-9 jam. Menurut Dermawan et al. (2017), Pembekuan cepat akan menghasilkan kristal es berukuran kecil sehingga akan meminimalkan kerusakan tekstur bahan yang dibekukan. Di antara teknik pembekuan cepat yang dipakai industri adalah Air Blast Freezer (ABF).

Pembekuan ikan adalah menyiapkan ikan untuk disimpan di dalam suhu rendah (cold storage) untuk mengawetkan sifat-sifat alami ikan. Pembekuan menggunakan suhu yang rendah, jauh dibawah titik beku ikan dan mengubah hampir seluruh kandungan air pada ikan menjadi es, tetapi disaat ikan beku dilelehkan kembali untuk digunakan, keadaan ikan akan kembali seperti sebelum dibekukan (Mursyid, 2009). Hal ini sesuai dengan Dermawan, Syawaluddin, Abrori, Nelfiyanti dan Ramadhan (2017), menyatakan proses pembekuan cepat juga menyebabkan terjadinya kejutan dingin (freeze shock) pada mikroorganisme dan tidak terjadi tahap adaptasi mikroorganisme dengan perubahan suhu sehingga mengurangi resiko pertumbuhan mikroorganisme selama proses pembekuan berlangsung.

\section{Pengepakan}

Pengepakan bertujuan untuk melindungi loin yang telah dibekukan menggunakan pastik PE. Ikan yang telah selesai di kemas selanjutnya di simpa pada penyimpanan beku (cold storage) sampai akan di didistribusikan. Pada kemasan plastik diberi kode seperti tanggal produksi, jenis ikan, dan supier ikan.

\section{Penyimpanan Beku}

Loin yang telah disusun di dalam palet segera di masukkan ke dalam cold storage sampai loin akan di ekspor. Suhu cold storage adalah $(-18)^{\circ} \mathrm{C}-(-25)^{\circ} \mathrm{C}$. Cold storage merupakan ruangan penyimpanan dingin yang berfungsi untuk mengawetkan produk pertanian, peternakan maupun 
perikanan melalui proses pembekuan dengan menggunakan suhu $-30^{\circ}$ hingga $-60^{\circ}$, sehingga ikan yang tersimpan storage dapat bertahan antara 1 - 9 bulan bahkan $>$ dari 2 tahun (Siahainenia, et al., 2018).

Indera (2014) menjelaskan bahwa selama penyimpanan, kadar air dalam produk meningkat karena terjadi perubahan-perubahan pada komponen produk. Perubahan komponen tersebut dapat menyebabkan daya pengikat air produk menjadi turun sehingga kadar air bebas dalam produk menjadi meningkat. Hal ini sesuai dengan (Kusuma, Dewi, Wijayanti, 2017) yang menyatakan Driploss dan kadar air yang meningkat menunjukkan terjadinya kehilangan air pada produk selama penyimpanan. Air yang hilang terjadi selama pembekuan dan pelehan kemungkinan disebabkan penurunan kapasitas mengikat air setelah proses pelelehan yang disebabkan denaturasi dan agregasi protein khususnya myosin (Foruzani et al. 2015). menurut Akhtar et al., (2013) menjelaskan bahwa denaturasi protein dapat terjadi selama proses pembekuan sebagai akibat meningkatnya kekuatan ionic pada jaringan intraseluler yang diikuti migrasi air ke jaringan ekstraseluler.

\subsection{Pengendalian Mutu}

\section{A. GMP (Good Manufacturing Practices)}

Standar GMP dan daftar pertanyaan dari kuesioner yang digunakan yaitu mengacu pada Peraturan Menteri Perindustrian Republik Indonesia Nomor: 75/M-IND/PER/7/2010 tentang Pedoman Cara Produksi Pangan Olahan yang baik. Berikut cara perhitungan menggunakan skala likert untuk ruang lingkup lokasi pada kuesioner penilaian skala likert ada lima pertanyaan.

Tabel 1. Contoh Salah Satu Perhitungan Skala Likert Lokasi.

\begin{tabular}{|c|c|c|c|c|c|c|c|c|}
\hline \multirow{2}{*}{$\begin{array}{l}\text { Pilihan } \\
\text { Jawaban }\end{array}$} & \multirow[t]{2}{*}{$\mathbf{x}$} & \multicolumn{5}{|c|}{ Pertanyaan (F) } & \multirow[t]{2}{*}{$F\{x\}$} & \multirow{2}{*}{$\begin{array}{c}\%=\text { total } \\
\text { skor } / 150 \times 100\end{array}$} \\
\hline & & $\mathrm{X} 1.1$ & $\mathrm{X} 1.2$ & $X 1.3$ & $X 1.4$ & $\mathrm{X} 1.5$ & & \\
\hline SS & 5 & 7 & 12 & 11 & 9 & 11 & 250 & $129.6 / 150 \times 100$ \\
\hline$S$ & 4 & 23 & 18 & 19 & 19 & 19 & 392 & \\
\hline $\mathrm{R}$ & 3 & 0 & 0 & 0 & 2 & 0 & 6 & \\
\hline $\mathrm{KS}$ & 2 & 0 & 0 & 0 & 0 & 0 & & \\
\hline STS & 1 & 0 & 0 & 0 & 0 & 0 & & \\
\hline JUMLAH & & 30 & 30 & 30 & 30 & 30 & $648 / 5$ & 86,4 \\
\hline
\end{tabular}

Berdasarkan hasil perhitungan diatas rata-rata persentase adalah 86,6 yang berarti Sangat setuju. Hasil penilaian diatas sesuai dengan keadaan Perusahaan Pembekuan Tuna PT. X berlokasi di kawasan industri. Jalan sekitar pabrik dilapisi dengan paving blok. Sekitar lokasi perusahaan dapat dikategorikan bersih tidak ada sampah menumpuk serta pabrik jauh dari tempat pembuangan sampah umum, limbah atau pemukiman penduduk kumuh. Lokasi Perusahaan Pembekuan Tuna PT. X juga merupakan daerah yang tidak mudah terkena air atau banjir. Hal ini telah sesuai dengan Peraturan Menteri Perindustrian Republik Indonesia Nomor: 75/M-IND/PER/7/2010 tentang Pedoman Cara Produksi Pangan Olahan yang baik yang menyatakan pabrik harus jauh dari daerah lingkungan yang tercemar yang dapat menimbulkan pencemaran terhadap produk, jalan menuju tempat produksi seharusnya tidak menimbulkan debu atau genangan air dengan dipasang batu atau paving blok, lingkungan tempat produksi harus bersih dan tidak ada sampah menumpuk dan pabrik bebas dari semak-semak atau daerah sarang hama.

Tabel 2. Rekapitulisasi Jawaban Rensponden tentang Penerapan GMP, SSOP dan Pengendalian Mutu Terpadu di PT. XY Berdasarkan Skala Likert

\begin{tabular}{llccc}
\hline No & & Aspek & Interval Nilai & kriteria \\
\cline { 2 - 4 } & GMP & & & \\
\hline 1. & Lokasi & 86,4 & Sangat setuju \\
\hline
\end{tabular}


Aurelia Journal, Vol. 2 (1): 29-38

\begin{tabular}{|c|c|c|c|}
\hline No & Aspek & Interval Nilai & kriteria \\
\hline 2. & bangunan & 87,3 & Sangat setuju \\
\hline 3. & Fasilitas Sanitasi & 95,1 & Sangat setuju \\
\hline 4. & Masin/Peralatan & 92,3 & Sangat setuju \\
\hline 5. & Bahan & 92,8 & Sangat setuju \\
\hline 6. & Pengawasan Proses & 92 & Sangat setuju \\
\hline 7. & Produk Akhir & 93,3 & Sangat setuju \\
\hline 8. & laboratorium & 97,3 & Sangat setuju \\
\hline 9. & Karyawan & 97,8 & Sangat setuju \\
\hline 10. & Pengemas & 88,3 & Sangat setuju \\
\hline 11. & Label Keterangan Produk & 93,1 & Sangat setuju \\
\hline 12. & Penyimpanan & 93,3 & Sangat setuju \\
\hline 13. & Pemeliharaan dan sanitasi & 93,2 & Sangat setuju \\
\hline 14. & Pengangkutan & 92 & Sangat setuju \\
\hline 15. & Dokumentasi dan Pencatatan & 89,3 & Sangat setuju \\
\hline 16. & Pelatihan & 88,6 & Sangat setuju \\
\hline \multirow{2}{*}{\multicolumn{4}{|c|}{ Sangat setuju }} \\
\hline & & & \\
\hline 1. & Keamanan Air dan Es & 94 & Sangat setuju \\
\hline 2. & $\begin{array}{l}\text { Kondisi dan Kebersihan } \\
\text { Permukaan Kontak dengan bahan } \\
\text { Pangan }\end{array}$ & 94,2 & Sangat setuju \\
\hline 3. & Pencegahan Kontaminasi Silang & 91 & Sangat setuju \\
\hline 4. & $\begin{array}{l}\text { Menjaga Fasilitas Pencuci Tangan, } \\
\text { Toilet }\end{array}$ & 94 & Sangat setuju \\
\hline 5. & Proteksi Bahan-bahan Kontaminan & 97 & Sangat setuju \\
\hline 6. & $\begin{array}{l}\text { Pelabelan, } \\
\text { Penyimpanan } \\
\text { Pengunaan } \\
\text { Berbahaya }\end{array}$ & 95 & Sangat setuju \\
\hline 7. & $\begin{array}{l}\text { Pengawasan Kondisi Kesehatan } \\
\text { Karyawan }\end{array}$ & 97,2 & Sangat setuju \\
\hline 8. & $\begin{array}{l}\text { Pengendalian } \\
\text { Pengganggu }\end{array}$ & 93 & Sangat setuju \\
\hline & $\begin{array}{c}\text { Rata-rata } \\
\text { Pengendalian Mutu Terpadu }\end{array}$ & $\begin{array}{c}94,4 \\
92\end{array}$ & $\begin{array}{l}\text { Sangat setuju } \\
\text { Sangat Setuju }\end{array}$ \\
\hline
\end{tabular}

Dari hasil rekapitulisasi diatas dapat dilihat hasil dari penerapan GMP 92, penerapan SSOP 94,4 dan Pengendalian Mutu Terpadu 92 yang menyatakan hasil dari responden menyatakan Sangat setuju. Hal ini menunjukkan pengendalian mutu terhadap produk di Perusahaan Pembekuan Tuna PT. X dilakukan dengan sangat baik sehingga dapat menghasilkan prodk dengan mutu yang terjamin bagi konsumen.

\section{Kesimpulan}

Adapun kesimpulan yang dapat diambil dari penelitian yaitu proses pembuatan produk Pengolahan Tuna Loin Precooked Frozen di PT. XY adalah dimulai dari tahap Penerimaan bahan baku, Pelelehan (Thawing), Penyiangan (Butchering), Penyortiran, Pemasakan (Cooking), Pendinginan (Spray I dan II), Pengkulitan (Skinning), Pembersihan (Cleaning), Pengemasan (Packing I), Pemvakuman, Pendeteksi logam (Metal detector), Pembekuan, Pengemasan (Packing II), Penyimpanan beku dan pemuatan. Penilaian dari responden terhadap pengendalian mutu di 
Perusahaan Pembekuan Tuna PT. X dilakukan dengan sangat baik oleh perusahaan, dengan hasil skor yang diperoleh dari kuesioner penerapan GMP (Good Manufacturing Practices) 92, penerapan SSOP (Sanitation Standard Operating Procedure) 94,4 serta Pengendalian Mutu Terpadu 92, hal ini terbukti dari observasi (pengamatan) penulis di Perusahaan Pembekuan Tuna PT. X.

\section{DAFTAR PUSTAKA}

Akhtar S, Muhammad Issa Khan, \& Farrukh Faiz. (2013). Effect of Thawing on Frozen Meat Quality: A comprehensive Review. Pakistan Journal of Food Sciences. 23(4): 198-211.

Arieska P. K., Herdiani N. (2018). Pemilihan Teknik Sampling Berdasarkan Perhitungan Efisiensi Relatif. Jurnal Statistik. Vol 6 (2)

Astawan M., Nurwitri C. C., Suliantari, dan Rochim D. A. (2015). Kombinasi Kemasan Vacum Dan Penyimpanan Dingin Untuk Memperpanjang Umur Simpan Tempe Bacem. Jurnal Pangan. 24 (2), 125-134.

Atmiasri, Rochman S. (2011). Pendeteksi Logam Untuk Industri Makanan Berbasis PLC. Jurnal Teknik. 9 (10), 1912-1867.

Dermawan E., Syawaluddin, Abrori M. R., Nelfiyanti, Ramadhan A. I. (2017). Analisa Perhitungan Beban Kalor dan Pemilihan Kompresor Dalam Perancangan Air Balst freezer Untuk Membekukan Adonan Roti Degan Kapasitas $250 \mathrm{Kg} / \mathrm{Jam}$. Engineering and Sains Juornal. 1 (2), 141-144.

Djaali. (2008). Skala Likert. Jakarta: Pustaka Utama.

[FDA] Food and Drug Administration. (2011). Scombrotoxin (Histamine) Formation. Di dalam: Fish and Fishery Product Hazards and Control Guide. Washington: Departemen of Health and Human Service, Center

Foruzani S, Maghsoudloo T, Noorbakhsh HZ. (2015). The effect of freezing at the temperature of $-18^{\circ} \mathrm{C}$ on chemical compositions of the body of Lutjanus johnii. Aquaculture, Aquarium, Conservation and Legislation Bioflux. 8(3): 431-437.

Hafiludin. (2011). Karakteristik Proksimat Dan kandungan Senyawa Kimia Daging Putih Dan Daging Merah Ikan Tongkol. Jurnal kelautan. Vol 4(1)

Idrus, S., \& Hadinoto, S. (2018). Proporsi dan Kadar Proksimat Bagian Tubuh Ikan Tuna Ekor Kuning (Thunnus albacares) Dari Perairan Maluku.

Keputusan Menteri Kelautan dan Perikanan Republik Indonesia Nomor KEP.01/MEN/2007, tentang Persyaratan Jaminan Mutu Dan Keamanan Hasil Perikanan Pada Proses Produksi, Pengolahan dan Distribusi.

Kusnandar F. (2010). Memahami Aktifitas Air dan Hubungannya dengan Keawetan Pangan. IPB

Kusuma, Dewi \& Wijayanti. (2017). Perbedaan Jumlah Nutrisi Yang Hilang Pada Bandeng Beku Non Cabut Duri Dan Cabut Duri Selama Penyimpanan Suhu Rendah. Jurnal Pengolahan Hasil Perikanan. 20(1): 153-163.

Mariah. (2011). Pengendalian Mutu Pada Proses Produksi Tuna Loin (Thunnus sp) Dengan Metode Six Sigma.[SKRIPSI]. Institud Petananian Bogor.

Mursyid, S. (2009). Proses pengolahan ikan beku: Bogor : PT. Panca mitra multi perdana.

Mohammed, I.M.A. and S.H.A. Hamid. (2011). Effect of Chilling on Microbial Load of Two Fish Species (Oreochromis niloticus and Clarias lazera). J. Food and Nutrition, 1(3):109-113. 
Nasution Z., Ilsa M., \& Sari I. N. (2016). Study Vacuum and Non Vacuum Packaging on The Quality Of The Fish Balls Malong (Muarenesox talabon) During Cold Storage Temperature $\left( \pm 5^{\circ} \mathrm{C}\right)$.

Nofreeana A., Masi A., Deviarni I. M. (2017). Pengaruh Pengemasan Vakum Terhadap Perubahan Mikrobiologi, Aktifitas Air Dan pH Pada Ikan Pari Asap. Jurnal Teknologi Pangan. 8 (1), 66-73.

Rahman, I.G., Sukmiwati M., Dahlia. (2015). Pengaruh Metode Pemasakan Berbeda Terhadap Karakteristik Tepung Ikan Betok (Anabas testudineus).

Retnawati, H. (2014). Teori Respons Butir dan Penerapannya (Untuk Peneliti, Praktisi, Pengukuran dan Pengujian, Mahasiswa Pascasarjana. Yogyakarta: Parama Publishing.

Retnawati, H. (2010). Perbandingan Akurasi Penggunaan Skala Likert dan Pilihan Ganda Untuk Mengukur self-regulated learning (SRL). Fakultas Matematika dan IImu Pengetahuan Alam.. Yogyakarta.

Sari, S.F. (2019). Pengaruh Perbedaan Metode Pencairan (Thawing) Terhadap Kualitas Kimia Daging Abalon (Haliotis asinina) Beku. Vol 14(2):106-109

Saragih, Ruben Joey. (2013). Analisis Bahaya dan Titik Kendali Kritis pada Penanganan Tuna Steak di PT Graha Insan Sejahtera, Muara Baru. Jakarta. Tersedia online :http://media.unpad.ac.id. diakses tanggal 20 Juli 2015.

Siahainenia, S.M. (2018). Stabilitas Harga Ikan Di Kota Ambon Melalui Peran Cold Storage Optimasi Produk dan Efisiensi Teknis. Jurnal PAPALELE. Vol 2 (2).

Sugiyono. (2012). Memahami Penelitian Kualitatif. Bandung: ALFABETA.

Wahyono, S.B., Hardianto, D., \& Miyarso, E. (2014). "Pengukuran Indeks Etos Belajar Siswa di Daerah Istimewa Yogyakarta". Jurnal Kependidikan, 44(1), 51-63.

Wodi, S.I.M., Trilaksani, W., Nurilmala M. (2018). Histamin dan Identifikasi Bakteri Pembentuk Histain Pada Ikan Tuna Mata Besar (Thunnus obesus). Jurnal Teknologi Perikanan dan Kelautan. Vol 9 (2):1-10. 